\title{
FRENCH FEMINIST THEORIES IN WENYI LILUN OF THE $1990 s^{1}$
}

\author{
CHEN YA-CHEN \\ Purdue University (USA)
}

In the People's Republic of China ${ }^{2}$, one of the front lines to embrace Western feminist theories ${ }^{3}$ was made up of a subset of the scholars, who were trained in foreign languages and literature and interested in gender studies ${ }^{4}$. These Chinese scholars' translation of feminist thoughts into Mandarin Chinese and their analyses and revisions of Western feminist theories were important vehicles that brought feminist thoughts from the West into China ${ }^{5}$. This front line was a key factor in terms of how Western feminist theories were transferred into China.

After Chinese women had the opportunity to hear about and know feminist theories, the way Western feminism was received in China ${ }^{6}$ became worth fur-

1. I am more than thankful for the following scholars: Evelyn Blackwood, Geraldine Friedman, Sally Hastings, Wendy Larson, Rebecca Nedostup, Patricinio Schweickart and Marcia Stephenson (in the alphabetical order of surnames).

2. In this article, the words, "China» and "Chinese," refer to communist China only -not including Taiwan and the greater China-.

3. Western feminisms were a part of the Western theoretical influx, which almost all the nonWestern nations could not but contend with, in modern era (JAYAWARDENA, Kumari: Feminism and Nationalism in the Third World, London, Zed Books, 1986, pp. IX-X and 1-24).

4. Among all the departments in Chinese academies, departments of foreign languages and literature contained the most qualified scholars to cope with theoretical texts written in Western languages. Thanks to their proficiency in Western languages, upon which their Western literary studies were based, members of this department could access Western feminist theories -including Western literary feminist theories- more professionally than those in other fields. In addition to these people, Chinese sociologists who are good at Western languages were also important for the perception of Western feminisms in China.

5. With regard to a rough historical outline about feminist activism and academic feminism in China, please see Western scholarly research by Phyllis Anders, Tani Barlow, Susan Brownell, Christina Gilmartin, Gail Hershatter, Emily Honig, Kay Johnson, Susan Jolly, Ellen Judd, Wendy Larson, Lisa Rofel, Judith Stacey, Joseph Stalin, etc (in the alphabetical order of surnames).

6. The initial feminist publications in China had almost no problems in being accepted by important presses, prestigious journals, or even mainstream mass media. This was because most East Asian feminist ideology was a tool for the whole nations to modernize themselves 
ther investigation. In order to accurately analyze the details of Chinese feminist literary research, I surveyed all the articles related to purely Western feminist literary theories in Wenyi lilun (文藝理論Literary and Artistic Theories) during the $1990 \mathrm{~s}^{7}$. I chose this journal because of its academic prestige, which the fact that almost every prestigious American university's Asian library has this journal could prove. Another proof of its academic prestige was perhaps related to its early establishment and being an academic survival of the harsh Cultural Revolution. It was established in 1973 -around three years before the Great Cultural Revolution was over-. This journal's fortitude and longevity even after all kinds of serious hurts at the end of the Great Cultural Revolution highly deserved academic respect. The other reason to select this journal ${ }^{8}$ was because of its location in Beijing: the capital of China, and the most qualified representative of the whole nation. In addition, Wenyi lilun accepted articles addressing Western literary and artistic thoughts. Authors of journal articles in Wenyi lilun were located almost all over the whole communist China in the 1990s?.

\section{A GREETING TO THE WEST}

In the 1990s, Chinese research on Western feminist literary theories contained at least three characteristics: first, a greeting to the West; second, a socio-political avoidance of practical feminist activism and women's radical social movements; and third, a French theoretical orientation after most AngloAmerican feminist thoughts were already introduced to pre-1990 China (see appendix).

around the end of the $19^{\text {th }}$ century and the beginning of the $20^{\text {th }}$ century. It was questionable that whether male modernizers in East Asia were one-hundred-percent sincere and honest feminists. However, a lot of earliest East Asian feminist publications did not suffer from American earliest feminist writers' tragic destiny of being kicked out of the prestigious journals. The initial feminist publications in China were no exception among almost all the early East Asian feminist publications. The earliest Chinese feminist publications might not be very mature feminist theoretical publications. But they were basic feminist notions published in major magazines, newspapers, or books.

7. I would focus upon articles purely on Western feminist theories, neither feminist textual criticism nor other topics. Take Wenyi lilun of the 1991 for instance. There were entirely around 382 articles. Among them, there were approximately 103 pieces about Marxism, socialism, Leninism, Maoism as well as the CCP propaganda about literary thoughts. There were around thirty papers on comparative literature. As for articles about non-feminist literary theories and textual criticism, such as narratology, realism, rhetoric, aesthetics, and so on, there were more than one hundred and ninety articles. Forty-seven papers were about Chinese literary thoughts and textual criticism. Two articles were about Taiwanese literature, and two pieces were feminist textual criticism.

8. Its founder was renmin daxue xubao ziliao she (人民大學書報資料社Data Center of Publications and News at Renmin University).

9. Other journals, such as Waiguo wenxue (外國文學Foreign Literature) in Beijing University, are also prestigious. However, most American university libraries do not have them. Therefore, these journals do not have as many American academic readers as Wenyi lilun. With difficulties in accessing all the journals issues of Waiguo wenxue of the 1990s, I am not able to survey and analyze Waiguo wenxue in America. 
Chinese theorists' access to Western feminist theories might be a reflection of the government's "Open Door Policy» toward the West. Roughly, after the middle of the 1980s, China transferred feminist theories from the West -mainly Anglo-American feminist notions-. One of the initial systematic transfers of Western feminism in Chinese literary academia began in the late 1980s, especially in 1988 and 1989. Zhu Hong (朱虹) and others started to summarize, outline, and apply feminist thoughts that were inside of Western feminist scholars' publications, such as Simone de Beauvoir's The Second Sex. Most of them focused solely on primary literary texts instead of ontological or epistemological discourses. Beijing University started to offer the first class about Western feminist literary criticism around that period of time. Later in the early 1990s, the Chinese publisher, henan renmin (河南人民出版社), issued one of the most well accepted Chinese digests of feminist discourses, Meng Yue (孟悅) and Dai Jinhua's (戴錦華) Fuchu lishi dibiao (浮出歷史地表Voices Emerging Into The Foreground of History: A Study of Contemporary Chinese Women's Literature).

Politically speaking, this appropriation more or less coincidentally matched the People's Republic of China's strong governmental motivation to re-establish the PRC's positive relationship with the West. Although the Tiananman Square Incident (天安門事件) in June $1989^{10}$ indirectly decreased the Western world's friendship with the PRC, Chinese communism insisted on an "Open Door Policy» in terms of diplomatic relationships ${ }^{11}$. What the West was in their mind referred to Euro-American advanced countries, which the US represented.

In brief, Communist China opened herself to greet the West. Hence the transplant of Western feminist theories onto China could indirectly correspond to the PRC's "Open Door Policy» toward the West. Judging from the fact that those who began transplanting Western feminism were safe and sound, the transplantation of Western feminisms to Chinese soil was one of the first projects approved by the Chinese communist government. Without this approval, Western feminist theories would probably have not been transplanted into the PRC.

10. Gorbachev's visit was the right timing to start the Tiananman Square Incident. International media's cameras were already ready in the Beijing area to record Gorbachev's visit to the whole world. They would of course not miss the Tiananman Square Incident. In other words, the Chinese communist government was impotent to veil the existence of this social movement under the pressure of international media. Otherwise, it was likely that this social movement would be silenced and mis-interpreted by the CCP (Chinese Communist Party).

11. For example, in 1991 Qian Oichen (錢其琛) went to Poland, Czechoslovakia, Hungary, Romania, Spain, and Greece. In the same year the PRC invited the British and Italian premiers to Beijing. Li Peng (李鵬) in 1992 visited Spain, Switzerland, Italy and Portugal. He also made a face-to-face meeting with then US president, George Bush, senior. 


\subsection{A Propensity to Evade Practical Feminist Activism and Women's Radical Social Movements without Communist Governmental Approval}

Among articles purely on Western feminist literary theories in Wenyi lilun of the 1990s, almost all the authors adopted terminologies such as écriture féminine, deconstruction, and phallocentrism. Hélène Cixous, Luce Irigaray, and Julia Kristeva, feminist interpreters of Lacanianism, Freudianism, Derridianism, Foucultianism, and Deconstructionist theories, were also emphasized. The adoption of critical terms and their emphasis strongly indicated a preference for feminism as a theory over feminism as practice.

According to my survey of Wenyi lilun issued in Beijing (北京) in the 1990s, there were at least thirteen papers purely focusing on Western feminist thought ${ }^{12}$. Let me briefly mention these papers in the following paragraphs (see appendix $)^{13}$.

In «Xin shiqi nüxing zhuyi wenxue piping shuping»(新時期女性主義文學 批評述評Feminist Literary Criticism on a New Age), Lin Shuming (林樹明) defined the characteristics of feminism: a critique of phallocentrism, a quest for women's self-awakening, a re-evaluation of literary history, and an encouragement of écriture féminine. Lin Shuming (林樹明) took feminist notions, such as phallocentrism and women's writing, into consideration but failed to include feminist social movements, one of the most important parts of American feminism. In addition, Lin Shuming commented on androgygny as well as the inter-relationships among feminism, post-structuralism, Marxism, and realism. When discussing «liangxin gungti» (兩性共體 androgyny), Lin Shuming ${ }^{14}$ pointed out the concept that some of the characteristics of écriture féminine could defeat or deconstruct masculinity. What Lin tended to underlined was in fact an ideological and epistemological repetition of chauvinism. What Lin

12. I would like to regard these paper writers as researchers in the field of feminist and gender studies no matter whether they were men or women and no matter what field their terminal degrees were in. Men's participation in East Asian feminism was common because the beginning of almost all the East Asian feminist thoughts was not to directly fight against male-centeredness but to help male elites modernize and reform their nations. No matter in activist levels or academic aspects, East Asian feminism could seldom remove male participants or expel men. Chinese feminists were no exception. No matter whether they were truly male feminists, they did participate in Chinese academic feminism by publishing these journal articles.

13. I simply summarize these journal papers in order to show how Western feminist thought was represented in Wenyi lilun of the 1990s. My summary was not to argue out the depth of any feminist theorization. My summary aims only to facilitate my comments on these Chinese feminist theoretical appropriators' choice of French feminist theories as well as their cross-lingual and cross-cultural surviving-strategies within the socio-political trends of the 1990s.

14. Lin Shuming highlighted three key points. First, androgyny did not exclude all the differences of sexes and gender. Second, androgyny could not afford the challenge from the practical creative writing. In Lin's opinion, what to write or how to write could not be factors to make sure whether or not a literary work was a piece of écriture féminine. Nor could the first person narration, which was frequently adopted by woman writers, be the reason why a work belonged to écriture féminine. Third, androgyny could not be requirement for literary pieces. 
Shuming ${ }^{15}$ meant by feminism had greater influence on literary criteria than all the other philosophical theories, such as structuralism and deconstruction. Lin highlighted that feminism, since the 1970s, adopted post-structuralist critiques on the one hand and severely criticized them on the other hand. This phenomenon, to Lin, was the reason why feminism of various kinds never declined when post-structuralism faded away gradually.

Zhang Jingyuan (張京媛 $)^{16}$ comparatively emphasized the origins of different Western feminist branches: French and American branches. According to Zhang, French feminism, among the Western feminist schools, played one of the most important roles, and was inspired by Derridian post-structuralism and Lacanian psychoanalyses. Similar to Zhang's interest in French feminism, Ma Xinguo (馬新國) ${ }^{17}$ paid special attention to the French Freudianism and Derridianism that Simone de Beauvior adopted. Zhang Yanbing (張岩冰) ${ }^{18}$ went further into Hélène Cixous's écriture féminine, Luce Irigaray's parler femme, and Julia Kristeva's semiotics. Zhang Yanbing remarked that all of them were more or less affected by Lacan and Derrida.

Zhou Leshi (周樂詩), Liu Siqian (劉思謙), Wang Ning (王寧), Rao Pengzi (饒 茫子) and Chen Lihong (陳麗虹) inserted their local and overseas Chinese concerns into some French feminist concepts, such as écriture féminine. For instance, Zhou Leshi ${ }^{19}$ affirmed that China's transfer helped re-examine, re-modify, and

15. This part of Lin Shuming's opinions was shown in "Nüxing zhuyi piping yü makesi zhuyi ji xianshi zhuyi shixue» (<女性主義批評與馬克思主義及現實主義詩學〉 《Feminist Criticism, Marxism, and Poetics of Realism», Wenyi lilun, 11 (1993), pp. 124-127) and "Nüxing zhuyi wenxue piping yü hou jieguo zhuyi» (<女性主義文學批評與後結構主義〉 «Feminist Literary Criticism and Post-Structuralism», Wenyi lilun, 10 (1992), pp. 157-165).

16. Zhang Jingyuan's (張京媛) journal article was entitled «Cong xünzhao ziwuo dao dianfu zhuti: dangdainüxing zhuiwenxue piping de fazhanqüshi»(<從尋找自我到顛覆主體: 當代女性主義文學 批評的發展趨勢> 《From A Quest for Self toward A Subversion of Subjectivity: The Development of Contemporary Feminist Literary Criticism», Wenyi lilun, 10 (1992), pp. 166-171). In this paper, Zhang believes that French feminism aims to deconstruct the whole Western cultural tradition of logocentrism. American feminism was affected by Raymond Williams, and took advantage of mass media, such as movies, to change the traditional social ideology.

17. Ma Xinguo's paper was entitled «Ping nüquan piping xin lishi piping ji houxiandai zhuyi wenxue de fazhan tezheng qüshi» (評女權批評.新歷史批評及後現代主義文學的發展特徵趨勢《On The Developing Characteristics and Trends of Feminism, New Historicist, and Post Modernist Criticism", Wenyi lilun, 8 (1994), pp. 74-82). Ma delineated the interactions between feminism and other theories. According to Ma, Simone de Beauvior and Elaine Showalter adopted Freudianism and Derridianism. And Marxism, which was based upon post-modernism, was also one of the methodologies that feminists used. Ma also mentioned Adorno and pointed out how much sociology, linguistics, psychology, and cultural study influenced contemporary literature. And Marxism, which was based upon post-modernism, was also one of the methodologies that feminists used.

18. Zhang Yanbing's paper was entitled «Faguo nüxing zhuyi wenxue piping de yüyan lilun» (法國 女性主義文學批評的語言理論 《The Theory of Language in French Feminist Literary Criticism», Wenyi lilun, 10 (1998), pp. 120-126).

19. Zhou's paper was entitled «Huanzhuang: zai bianyüan he zhongxin zhijian (nüxing xiezuo chuangtong he nüxing zhuyi wenxue piping celüe» (換裝: 在邊緣和中心之間(女性寫作傳統和女性 主義文學批評策略) «The Change of Garments: Between the Margin and the Center (Women's Writing Tradition and Strategies of Feminist Literary Criticism)", Wenyi lilun, 11 (1993), pp. 128- 
re-develop Western feminisms. After summarizing both the French feminism and the American feminism, Zhou then distinguished the differences among human beings (人), female/women(女人), and individual person (個人). Liu Siqian $^{20}$ rethought the problematic of modernity in Chinese women's literature. Wang Ning ${ }^{21}$ listed the similarities of both Chinese and Western écriture féminine. Moreover, Wang also affirmed that the narratology in female language was necessary for the development of écriture féminine. Rao Pengzi (饒芃子) and Chen Lihong (陳麗虹) ${ }^{22}$ analyzed overseas Chinese woman writers. The cultural diversity, the dynamic diaspora, and the marginal-ness of these overseas writers, for both Rao and Chen, were what could radically subvert the patriarchal self-centered-ness.

Wen Jiehua (文潔華) and Li Jikai (李繼凱) explored different gender factors that were related to literary originality and evaluation. Li Jikai (李繼凱) $)^{23}$ clarified the interrelationships among sexology, literature and arts. Sexology, to Li, was not just literary themes but also the motivation and the originality of literary writings. Wen Jiehua (文潔華) ${ }^{24}$ thought that Western feminist aesthetics pursued "negative aesthetics," which was in contrast to the phallocentric binary logic. A quest for authentic femininity was the key to the post-patriarchal art, which should be close to daily life, culture, and nature with no fixed outer

134). Zhou stressed the political strategies for the authentic femininity to subvert the phallocentric convention: a mimesis of the male subjectivity as an intervention from the margin toward the center, and an androgyny as an ideal to combine both the masculinity and the femininity.

20. Liu's article was entitled “Zhongguo nüxing wenxue de xiandaixing» (中國女性文學的現代性 The Modernity of Chinese Women Literature, Wenyi lilun, 4 (1998), pp. 47-58).

21. Putting feminist theories into practice in Chinese literary pieces, in Wang Ning's (王寧) opinion, could not merely question but also re-construct Western feminism. In «Nüquan zhuyi lilun yü zhongkuo dangdai nüxing xianfong wenxue» (女權主義理論與中國當代女性先鋒文學 《Feminist Theory and Contemporary Chinese Woman's Avant-garde Literature», Wenyi lilun, 2 (1996), pp. 111-117), Wang listed the similarities of both Chinese and Western écriture féminine: first, the transcendence of the self and the previous writers in terms of the artistic style; second, a strong consciousness to create a world of the self; third, an attack of heroic male-centered-ness; fourth, a focus on trivial details as a post-modernist exploration of the immediacy of experience; fifth, a deployment of the sensitive psyche; sixth, a metaphysical meditation of the heterosexual interrelationships towards a Chinese version of existentialism. Moreover, Wang placed an emphasis on the significance of an escape from the phallocentric notions of the binary oppositions.

22. Their paper was entitled «Haiwai nü zuojia ji qi wenban de lilun toushi» (海外華文女作家及 其文本的理論透視 "An Investigation to Overseas Chinese Woman Writers and Their Texts", Wenyi lilun, 2 (1998), pp. 62-73). They use feminism and cultural study to analyze the overseas Chinese woman writers: Chen Ruoxi (陳若曦), Ouyang Zi (歐陽子), Yu Lihua (於梨華), Zhao Shuxia (趙淑俠), and Nie Hualing (聶華玲) from Taiwan, Hong Ying (虹影) and Zha Jianying (查 建英) from China, and Sun Ailing (孫愛玲) from the Southern East Asia.

23. Li's paper was entitled «Wenyi xingxue chulun» (文藝性學初論 《An Introduction to Literary and Artistic Sexology", Wenyi lilun, 7 (1994), pp. 51-58).

24. Wen Jiehua's paper was entitled «Xifang nüxing zhuyi meixue: fazhan yü piping» (西方女性 主義美學:發展與批評 《The Western Feminist Aesthetics: Development and Criticism», Wenyi lilun, 3 (1998), pp. 45-52). Wen noted that feminist aesthetic formula attacked Kant's stress on rationality and harmony, which resulted from understanding and imagination, and Kant's jargon of the ideal observer. In addition, Wen Jiehua challenged the notions of «estrangeness» and «de-familiarness," celebrated by both formalism and modernism. 
forms. The so-called "genius» and "sublimity» that the traditions affirmed were never highly honored. Besides, feminist art was not necessarily women's art.

Compared with the above-mentioned Chinese journal articles, Western feminist theorists' scope was interdisciplinary, including fields such as sociology, anthropology, history, ethnology, politics, legislation, and law. In this Chinese journal of the 1990s, only French feminist theories of Luce Irigaray's, Julia Kristeva's, and Hélène Cixous's seemed to be especially highlighted. In Wenyi lilun of the 1990s, this Chinese cross-lingual and cross-cultural preference for the three dominant French feminist theorists indicated not merely the theoretical content of the French feminist writings as an object of academic worship ${ }^{25}$. It also implied these French feminists' non-activist career backgrounds -namely, career backgrounds of literature, linguistics, philosophy or psychology-. In other words, these French feminist scholars were farther away from practical social movements, such as political petitions, radical parades, reforms of legislation, fights against governmental patriarchy and so on.

In addition to a larger scope covering various fields, feminisms, particularly in the US, had one more facet and that was activism. Typical of the US feminist perspective, Susan Ehrlich used her critical linguistic methodology to investigate a case of sexual harassment on the campus of York University ${ }^{26}$. Not only her feminist concepts were simply written but they were also practically applied to courtroom litigation. Also, Mary Koss, a researcher studying rape and sexual harassment on campus, conducted a practical investigation of college-age women students' reactions to issues such as rape and sexual violation at Kent University ${ }^{27}$.

In Wenyi lilun of the 1990s, Chinese scholars' love for French theories lied not just in the theoretical content of their writings but also in their non-practical career backgrounds of literature, linguistics, philosophy or psychology. The love for non-practicality implied the communist governmental oppression of social movements or activism organized by citizens themselves. Many contemporary American feminist theorists, though not all American feminists,

25. Some feminist scholars with backgrounds in Communist China suspected that Zhang Jingyuan's translation of the three French feminist theorists in Dangdai nüxing zhuyi wenxue piping (當 代女性主義批評 Contemporary Feminist Criticism) indirectly initiated the French flavor in Wenyi lilun of the 1990s. I do not mean to deny the influence of Zhang's translation. However, I hesitate to believe that only one book could easily dominate Wenyi lilun of the 1990s. In addition, Zhang Jinyuan's book introduced not merely Hélène Cixous, Luce Irigaray, and Julia Kristeva but also Anglo-American feminist theorists, such as Mary Jacobus, Adrienne Rich, Elaine Showalter, Susan Gubar, Sandra Gilbert, Juliet Mitchell, Gayatri C. Spivak, Mary Poovey, Jacqueline Rose, etc. It was not extremely convincing that all these Anglo-American feminists in Zhang's book did not seem to impact on Chinese reception of Western feminist theories very much but the French part of the same book affected Wenyi lilun so deeply in the 1990s.

26. EHRLICH, Susan: "Critical Linguistics as Critical Methodology», in Sandra Burt and Lorraine Code (eds.): Changing Methods, Toronto, Broadview Press, 1995, pp. 60-71.

27. Koss, Mary: «Hidden Rape: Sexual Aggression and Victimization in a National Sample in Higher Education", in Ann Wolbert Burgess (ed.): Rape and Sexual Assault, New York, Garland Press, 1988, Vol. 2, pp. 8-10. 
had diverse career backgrounds that enabled them to practically deal with the cases that inspired feminist theories. For instance, feminist theorist Catharine MacKinnon was a lawyer before she taught in law school as both a law professor and a feminist. Not only did her previous career background enable her to address sexual problems in daily life with an attorney's professional ability and knowledge, but her academic work showed her awareness of the importance of practicality ${ }^{28}$.

In addition, the interdisciplinarity that Western women's and gender studies emphasized strongly indicated the diversity of Western gender researchers' backgrounds. For instance, a feminist scholar in the West, though probably not having any other job outside of campus, might be an anthropologist, a sociologist, an activist and so on at the same time. Few of the Chinese theorists, whose articles I surveyed, applied feminism to activist practice or women's radical social movements. Compared with the above examples of American feminist research, Chinese scholars seldom participated in any parades or social movements about Chinese issues of spousal abuse, rape, and sexual harassmentthough "[c]ases of sexual harassment of women [were] common in China ${ }^{29}$. Fulian (婦聯All-China Women's Federation) even exposed a horrifyingly ugly fact that a huge number of recent campus sexual harassment and sexual violation resulted from schoolteachers who lacked psychological balance and hurt female students ${ }^{30}$.

\section{A FRENCH INFLUENCE}

Generally speaking, China's appropriation of Western feminist concepts in this journal of the 1990s tended to draw from French feminists rather than their American counterparts. This Sino-West feminist selective filtering occurred during cultural transfers. Chinese theoretical appropriators took what they found the most useful and dropped what they were less able to acculturate in their local environments. Let me roughly sketch some well-known American feminist thought that Chinese scholars failed to put equal emphasis on in their transfer of Western feminisms into this Chinese journal in the 1990s.

I would briefly enlist some American psychodynamics of marriage and family structures as examples. Gayle Rubin pointed out that women were exchanged as if they were commodities among men through marriages in patriarchal societies ${ }^{31}$. Nancy Chodorow re-interpreted women's desire to reconstruct the psychological triangular relationships among mother, father,

28. MacKinnon, Cathorine A.: From The Sexual Harassment of Working Women: A Case of Sex Discrimination, New Haven, Yale University Press, 1979, pp. 1-23.

29. Jankowiak, William: "Parental Affection in the Chinese Family», in Susan Brownell and Jefferey N. Wasserstrom (eds.): Chinese Femininities / Chinese Masculinities: A Reader, Berkeley, University of California Press, 2002, p. 368.

30. The source came from the on-line Dajiyuan bao (大紀元報Dajiyuan news: www.epochtimes. com) dated August 7, 2002.

31. Rubin, Gayle: "The Traffic in Women», in Linda Nicholson (eds.): The Second Wave: A Reader in Feminist Theory, New York, Routledge, 1997, pp. 27-62. 
and children in family life ${ }^{32}$. There were of course many other Anglo-American feminist researchers' explorations. Some Chinese scholars, such as Zhang Jingyuan (張京媛), roughly mentioned similar notions in articles. However, politically speaking, CCP's early governmental policy tended to diffuse younger generations' original Confucian relationship with their biological fathers and to have communist leaders, such as Mao Zedong (毛澤東), as their «truer father». Various kinds of nation-wide political reforms and power struggles from the beginning of the PRC history to the end of the Cultural Revolution damaged Chinese folks' original parent-child relations. Even though the post-Maoist era was much less hurtful, the past political destructions of intimate parent-child relations were still influential. Margery Wolf, for instance, asked an official of the Beijing Women's Federation and got a tragic proof that the hurt was still not gone. "[Y]oung people learned bad habits from the Gang of Four and were neglecting or even mistreating the elderly members of their families» ${ }^{33}$. The above-mentioned well-anthologized and model feminist explorations in the US were not much emphasized in Wenyi lilun of the 1990s -not to mention less famous or younger American feminist scholars' newer or less classic research about these topics, such as Gwen Bergner's theoretical application of Oedipus Complex onto literary textual analyses published in $1998^{34}$.

Other American feminist theorists, such as Arlyn Diamond, Lee R. Edwards, Shulamith Firestone, and Michele Barrett, were seldom introduced in Wenyi lilun of the 1990s. In The Anthology of Experience, Arlyn Diamond and Lee R. Edwards collected essays that might enrich the sense of women's experience. Based on female sex as a class, Shulamith Firestone and Michele Barrett announced a new perspective to re-examine womanly economic and cultural identity in class struggles. Dale Spender discussed the Foucaultian paradox that the socalled "truth» relied on what constructed and managed discourse. She pointed out that men's domination of discourse trapped women by fictitious «truths» that men produced and controlled. Rowbotham noticed the double oppression that working-class women tolerated. According to Adrienne Rich, women might share a rich history and culture of the "woman-identified-woman" tradition through a "lesbian continuum». In brief, in terms of sexual orientation, social class struggles, racial and ethnic self-identity and so on, feminist concerns in the US were much more diversified than the gender issues Chinese scholars showed in the above-mentioned journal papers in the 1990s.

But how and why did the French school of feminism differ from the American one? In Sandra Gilbert's The Mirror and the Vamp, American feminism was

32. Chodorow, Nancy: "The Psychodynamics of the Family ", in Linda Nicholson (eds.): Op.cit., pp. 181-197.

33. Wolf, Margery: "The Setting of Chinese Women's Lives: Family Organization», in Revolution Postponed: Women in Contemporary China, Stanford, Stanford University Press, 1985, p. 187.

34. Bergner, Gwen: "Myths of Masculinity: The Oedipus Complex and Douglass's 1845 Narrative», in Christopher Lane (ed.): The Psychoanalysis of Race, New York, Columbia University Press, 1998, pp. 241-260. There were too many examples in the 1990s. It would be impossible for me to list every one of them. Therefore, I use only one as a concrete illustration. 
compared to a mirror, which reflected and represented the traditional literary canons and history from a feminist perspective. French feminism was a vamp, whose discursive strategies against patriarchy enchanted human beings. Toril Moi, who defined gynesis as a textualization of women, compared French feminist theory with American feminist criticism. French feminism, to Moi, was deeply influenced by Freudian psychoanalysis about the sexes. American feminism, according to Moi, was interested in what a woman really is. She saw it as less critical in comparison to the French theoretical approach. Moi regarded

«French feminism as theoretically conscious and elaborate, American feminism as more concerned with praxis, less alert to theory (...). American Criticism, as exemplified chiefly in Elaine Showalter's chapter on Woolf from A Literature of Their Own, [was] inadequate in comparison with a French reading of Woolf, dependent on the work of Jacques Derrida and Julia Kristeva. It [was] French feminism (...) that [could] make sense of the deconstructive potential of Woolf's work (...). American feminism, still tied to the values of traditional humanism, [could] only censure ${ }^{35}$.

One of the other most apparent distinctions between French feminism and American feminism was that American feminism included a concern with practic1al and radical feminist social movements. Take the discussion about motherhood and maternity for instance; French feminists and American feminists worked from extremely different directions even when they shared the same focus on the mother figure. French feminists were eloquent theoretically and philosophically. But without any governmental influence, American feminists concretely put abstract thoughts and ideology into practice. This was exactly the practical and radical part of US feminist activism. This was also what most Chinese feminist scholars lacked in the $1990 \mathrm{~s}^{36}$.

French feminists, such as Julia Kristeva, were interested in the psychological subtlety between mothers and sons. US feminists practically organized various mothers' organizations, such as Human Milk Banking Association in North America, Mothers' Association for Korean Americans ${ }^{37}$, Mothers Against Violence in America (MAVIA) ${ }^{38}$, Lesbian Mothers' Association ${ }^{39}$, and so on. Seldom did these non-governmental feminist kinds of mothers' organizations or associations exist in China of the 1990s.

In other words, a zeal for all kinds of feminist social movements characterized American feminism. Feminist institutions providing a 24-hour free service

35. MoI, Toril: Sexual/Texual Politics: Feminist Literary Theory, New York \& London, Methuen, 1988, pp. 7-11.

36. When Toril Moi and I pointed out American feminists' practicality and French feminists' theoreticality, we did not mean that American feminists were unable to deal with theories in the 1990s. Neither did we mean that French feminists were unable to have their own activism in the 1990s. We did not mean to generalize any kinds of feminisms. What I meant to point out was the fact that this comparative reading of different feminisms did exist in the 1990s.

37. http://www.imaka.org/application.htm.

38. http://www.mavia.org/resources.html.

39. http://www.aml-lma.org. 
for women victims, such as Battered Women's Shelters or Anti-Rape Crisis Centers or Equal Opportunity/Affirmative Action Affairs, exemplified the goals of American feminine activists who practically assisted victims of rape, sexual abuse, or marital or domestic violence. Andrea Benton Rushing's article entitled "Surviving Rape» was a good example. As an American feminist researcher, Rushing not only delivered academic talks and papers related to feminist thought in the US, but was also a rape victim herself, who was helped by professional feminist counselors. Rushing explained, "I have called the police, pressed charges, been hospital-examined, begun twice-a-week rape crisis counseling, even seen the pastoral counselor at Morehouse Medical School to talk about the politics of being raped $»^{40}$. This obvious tendency toward practical and radical activism was what both French and Chinese feminist scholars lacked.

Efforts made by other American feminist organizations to make a better contribution to women's welfare might be illustrated by the following: in the US, the combination of both theories and social activism yielded the establishment of organizations such as the National Organization of Women (NOW) founded by Betty Friedan in 1966. Another important American feminist organization was Women's Equity Action League (WEAL) that aimed to achieve equal treatment for women in terms of laws, tax, education, and employment. The National Council of Negro Women (NCNW) was a non-profit membership organization dedicated to improving the lives of African-American women. The National Coalition Against Sexual Assault (NCASA) supported sexually mistreated women.

In addition, third wave feminists managed movements that tried to "unite women across ethnic, racial, and whenever possible, class divisions ...[A]ctivists have organized workshops» to practically promote a greater transnational and cross-cultural sisterhood among women from various races, classes, religions, socio-political backgrounds, sexual orientations and so on ${ }^{41}$.

French feminist theorists did not emphasized this practical application of theories. Chinese scholars, like French feminists in this sense, barely included feminist social movements.

American feminist scholarship, which was very much connected with practical activism, emerged and matured in the context of its very strong grass-rooted political movement. It was buoyed, confirmed and reinforced by its connection to the experiences and ideas of the multitude of women who participated in the feminist movement in one way or another. In many ways, American feminism spoke of, and to, various American women: white women, black women, Native American women, middle-class women, women proletarians, women im-

40. Rushing, Andrea Benton: «Surviving Rape», in Paula Gunn Allen (ed.): The Woman Who Owned The Shadows, San Francisco, Spinsters, 1983, p. 134.

41. BARTKY, Sandra Lee: «Sympathy and Solidarity: On a Tightrope with Scheler», in Diana Tietjens Meyers and Alison Jagger (eds.): Feminist Rethinking the Self, Boulder, Westview Press, 1997, p. 177. 
migrants, etc. This explained in part why American feminist scholarship was less well received in China. Mainstream Chinese feminism of the 1990s, in many ways different from American feminism, did not include any concerns about women foreigners, women immigrants, women emigrants ${ }^{42}$, women of color and so on. French Feminism of the 1990s was largely theoretical in its genesis and in its constitution. It flourished in the abstract disciplines -primarily philosophy and psychoanalysis-. It did not rely on empirical research; it did not generally connect up with concrete social issues and problems -for example, workplace discrimination or sexual harassment-. It did not concern itself with a concrete political program. That is to say, French Feminism did not have, and in many ways did not need the support of a social group or a popular constituency -it was academic in the traditional sense- representing and appealing to the perspective of an academic elite, and dealing with problems that were largely "academic» -meaning removed from everyday, practical problems-. In contrast, American feminism was shaped by its connections to a "mass» women's constituency.

\section{A FEAR FOR THE CONSEQUENCE OF RADICAL ACTIVISM: SOCIAL MOVEMENTS, FEMINIST ORGANIZATIONS, AND CENSORSHIP IN THE VELVET PRISON}

Although Chinese journal articles I surveyed included not merely feminist literary theories but also other feminist theories, such as feminist psycho-

42. Frankly speaking, minority, foreigners, emigrants, and immigrants were usually used and sacrificed depending upon the Chinese majority's different political needs in different eras. Around the beginning of the twentieth century, Chinese minority's experiences in being oppressed were useful for the ROC to convince supporters of the need in overthrowing the Oing (淸) Dynasty and then constructing a brand new nation, which would never subjugate any minority. Sun Yat-sen (孫逸仙), the national father of the ROC, stressed influential emigrants and foreign human resources because he depended upon them to survive from calamities in exotic areas, such as Japan and England. As for the early ROC's attention to immigrants, it was probably because Western missionaries assisted cultural reforms, such as anti-foot-biding, Western educational systems, and new medical networks. In addition, immigrants' financial backgrounds helped Chinese folks modernize banks, universities, hospitals, etc. At the early ruling stage of the PRC, Chinese minority was used to celebrate the cultural space for racial multiplicity within the overall communist union (CHeUnG, Siu-Woo: «Subject and Representation: Identity Politics in Southeast Guizhou", $\mathrm{PhD}$ Dissertation, University of Washington, 1996, pp. 182-281). However, when they were no longer so useful and so necessary in terms of governmental and political benefits, they were often disregarded. For instance, «from the Anti-Rightist Campaign through the Cultural Revolution, [the original communist] policy of protecting heterogeneity was dramatically reversed... a more uniform socialist culture was ...to supersede the local differences» (SCHEIN, Louisa: "Gender and Internal Orientalism in China», in Susan Brownell and Jefferey N. Wasserstrom (eds.): Chinese Femininities/Chinese Masculinities, Berkeley, University of California Press, 2002, p. 387). Later on in the 1980s and 1990s, the minority was more differentiated. For instance, women in aboriginal tribes turned out to be a part of the representatives of minority cultures in China. Unfortunately, the minority was habitually eroticized, (self-)objectified, pointed out only to achieve Chinese communism's multicultural propaganda, and used as merely a tool to accomplish the national image-management (Ibíd., pp. 398-404). Whether there were truly sincere and non-political concerns about minority women, female immigrants, and women emigrants was still a riddle. I would take the Tibetan women's association for example in the middle part of this article. 
analysis, the topics or aspects that these papers cover were limited compared with the above mentioned ones. For instance, racial or multicultural issues of feminist studies were seldom mentioned in Chinese articles. That is to say, the feminisms transferred through these papers into China did not include all that the original Western theorists cover. Chinese feminist theoretical appropriators filtered, selected, and processed the original Western feminist theories as Chinese gatekeepers ${ }^{43}$. Thus Chinese readers about transferred Western feminist literary theories had a smaller and narrower scope than original feminist theories in the West.

Chinese researchers' preference for non-practicality, I argue, revealed their inability to practice radical feminist ideas due to the communist governmental control. Although not all Western feminists could put their theories into practice in a perfect way, Chinese feminists' lack of practicality was indeed one of their weaknesses. Not many of the Chinese feminist researchers could take radical and activist stances should women victims come forward at Chinese universities and approach their professors for help with sexual issues.

After a discovery of the "French flavor» that was more theoretical and contained less activism than American feminism, it was worth considering why Chinese scholars chose French feminism, especially when France was just one country in the West and could not represent the whole Western world. If the Chinese governmental policy was to greet the West, or to open China's door to the West, then why did Chinese feminist researchers embrace France more closely and opened their door to French theorists more enthusiastically than others according to what Wenyi lilun of the 1990s disclosed? Why were they afraid of or inclined to dislike American feminism?

The Chinese preference for non-practicality was clear in Wenyi lilun of the 1990s, and it was puzzling why the aspect of practicality seemed to be so deliberately omitted. If the ability to deal with the practical aspects of social feminism, such as organizing a national women's association and planning demonstrations for the right of abortion, would be helpful for Chinese women, then why did these Chinese feminist appropriators not develop practical organizations and feminist social movements?

Why did Chinese scholars avoid connection with social movements? Why was the consequence of the feminist social movement so intimidating to communist China? In order to find out possible answers to these questions, a brief probe into the Chinese socio-political world would be necessary. The following discussion will explore the social backgrounds and political consequences of social movements and feminist organizations in China that might influence women's and gender studies in China of the 1990s.

From 1965 to 1976, the Chinese Cultural Revolution restricted PRC's contacts with foreign academics. Well-educated elites in Chinese academies suf-

43. My exploration about Chinese feminist theoretical gatekeepers, such as their selective criteria, was in the final section of this article. 
fered during numerous communist political power struggles. Some of them were xiafang laogai (下放勞改sending down / reformed through labor), forced to leave their academic institutions, and then demoted to the countryside. Some of them could not tolerate the physical and spiritual torture they endured and died miserable deaths. Well-educated elites with knowledge of either international or Western -to be more specific, American- advanced research faced the most threat of danger.

The Tiananman Square Incident was probably one of the best examples to show Chinese people's fear of the results of social movements. Many "of the most active and prominent participants in the movement, and certainly such prominent leaders as Wang Dan (王丹), Wu'er Kaixi (吾爾開希), and Shen Tong (沈肜), worked closely with reform currents within and outside the [Chinese Communist] party ... Their primary goal throughout the Spring of 1989 was the creation of a legitimate space for dialogue with authority in debating and shaping the reform agenda» ${ }^{44}$-not to overthrow nor to eliminate the communist government-. However, what was threatening was the "ability of the students to control Tiananmen during the Soviet leader's ${ }^{45}$ visit [that] underlined their power to influence and directly challenge state policy at a time of maximum international visibility ${ }^{46}$. In other words, the Chinese communist authorities demonstrated that participation in non-approved social movements might cause disastrous results: either the ending was to die miserably, to be put in jail, to be expatriated, or to seek asylum in foreign countries. Even though freedom of speech and academic freedom were already taken for granted in the West's contemporary era, intellectuals' thoughts in China were still censored by the CCP .

"The slaughterers, the soldiers of the 27th army, used tanks, assault weapons, and bayonets (...) on people who (...) yelled only a lone slogan (...). They used automatic guns to mow them down so that the chests of all of the dead were soaked in blood (...).Their hands, chests, and legs were covered with blood» ${ }^{47}$.

Some comments said that the situation was even worse than the Cultural Revolution. A witness, after catching sight of the bloody scenes, expressed the concern that "China [is] sinking ... into the ... warlordism, fascism" ${ }^{48}$.

If the above-mentioned terror was the tragic result of social movements that attempted to influence Chinese society towards democracy and indirectly challenge government authority, then it might be understandable that Chinese feminists dared not directly become committed to social movements outside

44. Seldon, Mark: "Limits of the Democratic Movement», in Roger V. Des Forges, Luo Ning and Yen-bo Wu (eds.): Chinese Democracy and the Crisis of 1989: Chinese and American Reflectio, Albany, State University of New York Press, 1993, p. 126.

45. See my tenth footnote.

46. Seldon, Mark: Op.cit., p. 123.

47. Han, Mingzhu: Cries for Democracy: Writings and Speeches from the 1989 Chinese Democracy Movement, Princeton, Princeton University Press, 1990, p. 362.

48. Salisbury, Harrison Evans: Tiananmen Diary, Boston, Little, Brown, and Co., 1989, p. 175. 
of communist governmental levels. Even at the United Nations' conference on women in Beijing in 1995, what was said about feminist thoughts in that conference by Chinese speakers was said with the communist governmental approval. For example, Jiang Zemin (江澤民), the chairman of the CCP, ironically spoke as if he were the most qualified «teacher», "guide», "leader», or "director» of all the Chinese feminists ${ }^{49}$-regardless of the fact that Jiang himself was male without true experiences in any Chinese women's predicaments, and never proven to be a one-hundred-percent practical feminist in China-. This fact was a proof of how much Chinese feminist activism was under the CCP's political control and "guidance» in the 1990s. Whatever the CCP politically disapproved was hardly feasible in this conference. For instance, the CCP disallowed Taiwanese feminists to attend this conference as national representatives for Taiwanese women. Zheng Zhihui (鄭至慧) participated in this conference as simply an individual -not a ROC spokesperson for Taiwanese women at all-. Hence such a conference did not practically promote radical feminist activism ${ }^{50}$ in China -though it was not exactly hurtful for Chinese feminism-. Even in the post-Maoist era that was more liberal, "women [were] dependent on society, on the party, and on the state...women [were] doomed by their passive role» ${ }^{51}$. If social movements in the PRC were too dangerous for Chinese researchers in the field of gender studies, then was it safe for Chinese feminist appropriators to manage their own feminist organizations? If larger strikes in social movements were too dangerous, then were women's parades for some milder issues safer?

In the last decade before the new millennium, no major incidents occurred in which people were killed by the CCP because of their political or religious beliefs. Governmental permission still played an extremely influential role in the sanctioning and domination of intellectuals' academic projects. Take the Tibetan Women's Association for instance ${ }^{52}$. It was probably one of the rarely seen Chinese radical women's social movements that were not controlled by communist governmental powers ${ }^{53}$. The location of its website was in Canada, however. The location of the association was in India. The website did not

49. See Sinhuanet News (新華網新聞) dated September 4, 1995.

50. The Tibetan Women's Association, which I explore in the following paragraph, was an eloquent illustration for the fact that radical feminist activism, without communist political permission, could hardly survive in Chinese territory.

51. LI, Xiaojiang (李小江): «With What Discourse Do We Reflect on Chinese Women? Thoughts on Transnational Feminism in China”, in Mayfair Mei-hui Yang (楊美惠) ed.): Spaces of Their Own in Transnational China, Minneapolis, University of Minnesota Press, 1999, p. 271.

52. http://www.tibet.org/tibet.org/. The Tibetan Women's Association was a feminist organization. There are three fundamental concerns of the Organization: first, violations of Tibetan Women's Rights in Tibet, especially their reproductive rights; second, increasing torture and imprisonment of Tibetan women; third, discrimination against Tibetans in education, health and employment in Tibet.

53. There were other overseas women's organizations. For instance, Chinese Society for Women's Studies (海外中華婦女協會CSWS) was established in the United States in the 1990s. See the website: www.csws.org. 
exist in Chinese communist territory. The association did not, either. This suggested that the freedom to manage a large women's organization in China was not unlimited. According to their website, many Tibet activists became political prisoners. For example, fourteen nuns were jailed for taking part in peaceful demonstrations in Tibet, between 1989 and $1992^{54}$. All of the demonstrations were non-violent, involving less than half a dozen people and lasting less than five minutes. They become known collectively as the Drapchi 14. It was unlikely that Tibet women's organizations were approved of and welcomed by the Chinese communist government. And the cases in other areas of China were probably similar or not better than the Tibet situation ${ }^{55}$.

Even fulian (婦聯All-China Women's Alliance), which was founded under the support of the central administrative system, seemed to be obedient to the communist government ${ }^{56}$. Chinese feminist scholars might have seen fulian's governmental practice in action, such as "One Child Policy", and hence might not want to go that direction at all. Fulian did not seem to strive for women in aspects that were outside of the communist governmental concern about women. For instance, in the 1990s most Chinese women victims, if suffering rape, marital abuse, or sexual violation, still had no place to turn to ${ }^{57}$. Unlike

In Communist China, small women's organizations, such as funü chuanmei jiance wangluo (Women's Media Watch Network) or Shaanxi funü lilun hunyin jiating yanjiuhui (Shaanxi Association for Women and Family), regarded themselves as non-profit organizations without formal support from the central government of Chinese Communist Party (CCP). However, they were still much less influential than fulian in the 1990s. Some researchers wondered whether they "display[ed] the same rigid notion of political correctness... in negotiations» (HsIUnG, PingChun; JaschoK, Maria; Milwertz, Cecilia and Chan, Red: Chinese Women Organizing, Oxford \& New York, Berg, 2001, pp. 11, 193-226).

These small women's organizations in Communist China seldom called any radical strikes or parades on streets. Some of the members in these organizations confessed to me that it would be impossible for CCP to allow radical feminist social movements without governmental permission.

54. Drapchi Prison was notorious for its poor living conditions. Torture and ill-treatment by prison officials are commonplace. Political prisoners are often beaten severely and shocked with electric cattle prods. Nuns and other female prisoners have reportedly been raped. In Tibet, the current Chinese communist government was conducting a ruthless crackdown on any form of political dissent. Tibetan politics and religion are very closely linked, so the focus of this crackdown had been on monks and nuns of the Buddhist faith. Also see New York Times dated February 27, 2004.

55. Fulian, a part of Chinese communist women's organization, was an exception. Although fulian «claim[ed] to NGO status» (Hsiung, Ping-Chun; Jaschor, Maria; Milwertz, Cecilia and Chan, Red: Op.cit., p. 10), it was approved and affirmed by the CCP government.

56. Barlow, Tani E: «Theorizing Women: Funu, Guojia, Jiating», Genders, 10 (1991), p.146 and JIANG, Hong: «Feminine or (Un)feminine: Struggles over the Meanings of Femininity in Chinese Women's Literature», in Women and International Development, Michigan State University, Working Paper\#272, May 2001, p. 5.

57. Even fulian or other smaller women's organizations, such as hotlines and legal advice centers, tried to help women victims, their assistance was still limited when compared with what crisis centers in the West could offer. For instance, they usually forced rapists' or abusers' bosses to punish or fire the rapists and abusers according to interviews in Through Chinese Women's Eyes. It was still questionable whether they gave raped or abused women any 24-hour shelter, protec- 
American female victims assisted by organizations such as rape crisis centers, current Chinese women seldom had any specialists' legal representation or psychological counseling service from their own women's institutions. In other words, the Chinese feminist appropriators, whose journal articles I surveyed, might not feel comfortable and safe in their socio-political surroundings in terms of their own formal feminist organizations and social movements in China of the 1990s. An evident illustration was Ling Ding's (丁玲) complaint about women's double burden in private family life and public job markets in an essay entitled «Sangajie you gan» (三八節有感 «Thoughts» on March $8,1942)^{58}$. Two months after her critique was published, Ding was forced to "confess her 'errors' at a communist mass meeting ${ }^{59}$. This experience of Ding's might be too ancient to be directly lumped with my argument about the 1990s. However, such an incident happened before vigorous nation-wide communist power struggles -not to mention the worst era from the 1950s to the 1970s-. Although the milder post-Maoist era allowed feminist scholars, such as Li Xiaojiang (李小江), to complain about Chinese women's double burdens in academic publications, there was still never any radical feminist activism of Chinese women's own to fight against either the communist patriarchy or the governmental male-centered-ness in the 1990s.

One of the subtlest proves in the 1980s and the 1990s was probably how and where feminist scholars published their complaints about the CCP's insincerity. Some feminist Asianists, such as Emily Honig, criticized that women's liberation was never a main central concern for the $\mathrm{CCP}^{60}$. Other scholars, such as Phyllis Anders, Kay Johnson, Li Xiaojiang and Judith Stacey, strongly denied that Chinese women were really liberated by communists ${ }^{61}$. Almost all of these feminist protests against the CCP were written in or translated into English and then published outside of the territory that the CCP could dominate. These scholars' avoidance of writing their grievance in Mandarin Chinese and publishing their dissatisfactions in China was a clear illustration of how much they were afraid of the Chinese communist political power.

Even in the 1990s, there was still censorship in China repressing freedom of thought and speech more vigorously than the previous authoritative regime during the Cultural Revolution. Geremie Barmé, in an article entitled, "The

tive order, or sessions of psychological counseling twice a week exactly in the same way that Western feminist activists often supplied to victims in the 1990s. (For what American feminist activists provided to victims, please see Andrea B. Rushing's experience in this article).

58. The first publication of this article was in Jiefang ribao (解放日報 Daily News of Liberation) on May 9, 1942.

59. DinG, Ling (丁玲): «We de Chuangzuo Jingyan» (我的創作經驗 “My Experience in Literary Creation"), in Liangjun Yen (ed.): Ding Ling Yanjiu Ziliao (丁玲研究資料 Research Materials on Ding Ling), Tianjin (天津), Tianjin Renmin (天津人民), 1982, pp. 105-107 and LARSON, Wendy Ann: Women and Writing in Modern China, Stanford, Stanford University Press, 1998, p. 169.

60. HoniG, Emily: «Socialist Revolution and Women's Liberation in China -A Review Article», Journal of Asian Studies, XLIV-2 (1985), pp. 329-336.

61. LI, Xiaojiang (李小江): Op.cit., p. 380. 
Graying of Chinese Culture,» used the gray color to describe the morose socio-political aura ${ }^{62}$. Applying the terms of "Hungarian dissident poet Miklos Haraszti, Barmé [called] the ... situation in the People's Republic of China, in which the earlier forms of brutal military violence [were] increasingly replaced by a repressive, invisible violence partaken of by intellectuals themselves, a 'velvet prison'»63.

By mentioning the "commonplace that the Chinese intelligentsia (...) had a more compliant attitude (...) than intelligentsia in Eastern Europe» ${ }^{64}$, Barmé's assertion sounded both audacious and provocative. Yet he was not the only scholar pointing to this. More or less echoing Barmé, Judy Polumbaum predicated,

"Control [of thoughts and speech was] exercised through various means, both obvious and subtle, including the power to authorize and close down media outlets and other overt regulatory measures (...) personnel management, particularly the selection and removal of top editors; and various types of censorship, including creation of a climate conducive to self-censorship ${ }^{65}$.

People's Daily was repeatedly explored by a number of researchers as one of the best proofs of censorship.

"One student from the Beijing Foreign Languages Institute called for the removal of press censorship and pointed out that it was the strongest demand of the students that the press should "tell the truth» (...) Mu Yuan [the spokesman of the State

62. Barmé, Geremie: «The Greying of Chinese Culture», China Review, 13:2 (1992), Hong Kong, p. 2. Geremie Barmé commented on the leader cults continually promoted by the party propaganda machine in the 1980s and 1990s in the following terms: "While the Party promoted the great revolutionaries of the past to confirm its present authority, the masses often responded to them as revived deities, bereft of immediate political and historical significance, embodying rather traditional charismatic elements: Mao Zedong, the laconic and brilliant thinker and strategist, Zhou Enlai the loyal minister who works himself to death, Jiang Oing the fickle and crazed woman, Lin Biao an evil genius and a host of other revolutionaries who made history. Compared to the gray bureaucrats of today -Jiang Zemin, Li Peng, Zhu Rongji, et al.- who rose to power through murky bureaucratic infighting- these are real saints (or devils)» (Ibíd., p. 20).

63. CHow, Rey: «Visuality, Modernity, and Primitive Passions», in Primitive Passions: Visuality, Sexuality, Ethnography, and Contemporary Chinese Cinema, New York, Columbia University Press, 1995, p. 50. "A realm in which the crude and military style of Stalinist (or Maoist) rule with its attendant purges, denunciations, and struggles [had] finally given way (or was giving way, as was the case in China) to a new dawn of "soft», civilian government. Technocrats [reformulated] the social contract, one in which consensus [replaced] coercion (...). Censorship [was] no longer the job of a ham-fisted apparat, but a partnership involving artists, audiences, and commissars alike. This [was] "progressive censorship," and it had an aesthetic all of its own. The new dispensation [was] described in various ways: the Czech dissident Vaclav Havel [spoke] of it as «invisible violence," while Haraszti (...) dubbed it "the velvet prison.» And it [was] a prison with an aesthetic all of its own (self-)repression itself (...)become a form of high art» (BARMÉ, Geremie: "The Chinese Velvet Prison: Culture in the 'New Age,' 1976-89», Issues and Studies, 25-27 (1989-91), pp. 62-63).

64. BarmÉ, Geremie: «The Chinese Velvet...», op.cit., p. 61.

65. Polumbaum, Judy: «Professionalism» in China's Press Corps», in Roger V. Des Forges, Luo Ning and Yen-bo Wu (eds.): Op.cit., p. 301. 
Council], however, responded by saying that (...) the press (...) [had] to be constrained by the Constitution and law (...) and cannot report on whatever happens ${ }^{66}$.

Owing to the problem of their survival, People's Daily journalists were forced to avoid writing about what they disagreed with. It "[was] in effect not the [Chinese Communist] party's 'house organ', but has the even narrower function of representing those who happen to be in power» ${ }^{67}$. Owing to the specific socio-political condition, both the high-tech mass media and the press in China, right after the June Fourth student social movement «fully resumed its (...) function as the propaganda machine used by the Communist Party to rewrite history ${ }^{68}$-and manipulate the future-» ${ }^{69}$.

The censorship and (self-)repression in the "velvet prison» could perhaps served as one of the possible explanations for the reason why Chinese feminist appropriators were so keenly shunning American feminist activism in the 1990s. If they did appropriate American feminist activism into China, they would probably run too much risk and pay too high a price in their lives due to socio-political environment of the "velvet prison». Under the above-mentioned circumstances and censorship, it was perhaps too demanding to expect Chinese feminist savants to establish their own feminist organizations or to plan their own feminist social movements without any concerns or worries about the communist governmental attitudes at all.

\section{SOCIO-POLITICAL SITUATED-NESS OF CHINESE FEMINISMS}

In Wenyi lilun in the decade before the new millennium, Chinese theorists' enthusiasm for French feminist theorization revealed an unconscious avoidance of feminist activism and radical social movements. In other words, the PRC's governmental censorship of social movements prevented Chinese appropriators from forming social movements. Since social activism was one of the indispensable parts of American feminism, Chinese theorists' transfer of Western feminisms tended to neglect American feminist activism.

Chinese political restrictions seemed to conflict with the liberal attitude of PRC's "Open Door Policy». But as a matter of fact, no matter how much China opened herself, the PRC still had communist limitations in the 1990s. Judging

66. Mu, Yi and Thompson Mark V.: Crisis at Tiananmen, San Francisco, China Books \& Periodicals, 1989, pp. 127-128.

67. Ibíd., p. 126.

68. "In the extreme case, the People's Daily not only failed to print full accounts of what was taking place in the streets [during the Tiananmen square incident], but published what seemed to be ludicrous and irrelevant reports instead. Looking at the paper on the third day following the military crackdown, one would have no idea that anything had taken place in the streets at all. The front page was full of minor news from outlying areas, most attributed to provincial newspapers... This doubtless reflected a ban on coverage of the "real» news; but the lack of substance also suggests a deliberate work slowdown by reporters; and in addition, the ridiculous assortment of mundane stories that editors chose to run conveys a sense of the frustration they must have felt at the time» (TAN, Frank: «Epiphany of Press Reform», in Roger V. Des Forges, Luo Ning and Yen-bo Wu (eds.): Op.cit., p. 287).

69. Mu, Yi and Thompson Mark V.: Op.cit., p. 137. 
from all the Chinese social movements since the 1950s, I cannot deny that all of them were politically designed or planned to serve specific governmental slogans or targets. That is to say, the CCP censored, patronized, and controlled the beginning, the development, and the termination of all these social movements. It was still politically incorrect for Chinese citizens to organize any social movements simply according to the people's own choices.

To be more specific, even with the "Open Door Policy", communist China of the 1990s was still not completely open and liberal. Hence the unconscious yet dominant intention to evade feminist social movements, which could not serve any communist ideals at all, was not irrational. This was a possible interpretation for the reason why Chinese feminist theorists either unconsciously or consciously disliked any deeper devotion to feminist social movements.

Chinese feminist theorists' dearth of any deeper devotion to radical feminist social movements was probably one of the reasons why Western feminisms in China were so different than original Western feminisms in the West. After Lydia $\mathrm{H}$. Liu highlighted the necessity to rethink cross-cultural interpretation between the East and the West, I would like to rethink some possible Sino-West socio-political interpretation for China's unavoidable «change» or acculturation of Western feminisms ${ }^{70}$. First, Chinese political repression and lack of social liberty turned out to be the key points in how feminist and gender theories were developed and received differently in PRC. Second, a transnational and multicultural investigation into the transferal of feminist and gender theory to communist China became indispensable. In this sense, how Western feminisms looked in China was not actually how Western feminisms really were. How Western feminisms looked in China was different from how they originally looked in the West. It was, as a matter of fact, how Western feminisms were socio-politically situated in China.

Beyond a feminist comparative study of differences and similarities between Western feminists and Eastern feminists, this anthropological observation offered a possible answer to China's preference for French feminism over American activism. This probe into the repression of social movements, and the censorship in the "velvet prison" helped make sense of Chinese feminist savants' socio-political difficulties when they transferred feminisms from the West into Chinese communist territory. Under a fear for the consequence of practical activism, Chinese feminists could not but take refuge in French theorization. The way Western feminisms were socio-politically situated in China displayed the Chinese feminist scholars' necessary surviving-strategy that balanced their academic pursuits with their intellectual freedom. Such a survivingstrategy was a cross-lingual and cross-cultural one.

70. Liu, Lydia H: Translingual Practice: Literature, National Culture, and Translated modernity-China, 1900-1937, Stanford, Stanford University Press, 1995, pp. XV and 30; SPIVAK, Gayatri C.: In Other Worlds: Essays in Cultural Politics, New York, Routledge, 1988, p. 197. 


\section{FURTHER CROSS-LINGUAL AND CROSS-CULTURAL SURVIVING- STRATEGY}

To choose French theorization in order to dodge American feminism's practical activism and social movements might be a safe action for Chinese scholars to take in the 1990s. It was truly one of the surviving-strategies in Chinese academies of the 1990s. However, there were so many French feminist theorists. It might not be possible to transfer all of them. Which ones to be chosen was an unavoidable problem. To solve the problem required further cross-lingual and cross-cultural surviving-strategies. Chinese scholars' further cross-lingual and cross-cultural surviving-strategy was to apply American/Western academia's mainstream taste onto their decisions of which French feminist theorists to transfer. Why was the American/Western academia's mainstream taste their criterion? Maybe it was because American publications in English were easier and more accessible than publications in other Western languages for most Chinese scholars. Maybe it was because USA was the strongest representative for the whole West from Chinese perspective in the 1990s.

Among all the French feminists, Chinese appropriators decided which ones they preferred to introduce to China. For instance, Monique Wittiq, Catherine Clément, Sarah Kofman, Christine Delphy ${ }^{71}$, Toril Moi ${ }^{72}$ and others were not the most popular. Yet Luce Irigaray, Julia Kristeva, and Hélène Cixous were undoubtedly their favorites.

This Chinese literary academic journal exhibited its preference for these three French feminist theorists in the 1990s. I plan to use this as evidence. This evidence can prove that at least in the 1990s Chinese scholars filtered, decided and strategized what Western feminist theories and theorists to be localized in which ways for what reasons.

The preference for the three French feminist theorists in this journal of the 1990s was actually contrary to most Chinese scholars' Western language backgrounds. Chinese feminist scholars of the 1990s were usually more familiar with English, instead of French. Regardless of most Chinese scholars' average weakness in French language, Wenyi lilun displayed an obvious predilection for the three French feminists. Therefore, I would like to highlight Chinese crosslingual and cross-cultural impacts on the localization/sinicization of the three French feminist theorists in this specific period of time.

In terms of introductions of French feminist theories and theorists to China, theoretical appropriators' cross-cultural and cross-lingual knowledge and skill

71. Wang Zhihung (王志弘) translated one of Christine Delphy's article («Faguo nüxing zhuyi: diguo zhuyi de faming» (法國女性主義：帝國主義的發明 “French Feminism: An Invention of Imperialism»), in Gu Yanlin (顧燕悀) and Zheng Zhihui (鄭至慧) (eds.): Nüxing zhuyi jingdian: shiba shiji ouzhou qimeng, ershi shiji bentu fansi (女性主義經典：十八世紀歐洲啓蒙，二十世紀 本土反思 Feminist Canons: European Enlightenment in the 18 $8^{\text {th }}$ Century, Local Reflections in the $20^{\text {th }}$ Century), Taibei, Nushu (女書Fem Books), 1999, pp. 379-391).

72. The Department of Foreign Languages and Literature at National Taiwan University invited Toril Moi to give a speech in 1999. The impact of Toril Moi's speech was much less than that of Julia Kristeva's trip to China in the 1970s. 
were much more important than how the original Western feminist theories or theorists were in the West. No matter how theoretically strong Catherine Clément, and Monique Wittiq truly were in France, they were still not well known in America and China of the 1990s. Seldom did every theoretical appropriator in America and China enthusiastically introduced them by exerting American and Chinese academic power and making use of their cross-cultural and crosslingual capacities.

Similarly, the reason why Irigaray and Cixous were much more renowned and well liked by Chinese researchers was not because all the other French feminists were worse than these two. Whether they were better known in America and China more or less depended on American and Chinese translators' and introducers' willingness. If I compare Hong Kong with China, it would be even more understandable. Hong Kong of the 1990s did not have any obvious zeal for any French feminist theories. Hardly were the French feminists as famous and influential in Hong Kong as in China at that time. This was not because Hong Kong people looked down upon French feminists. It was because French feminists lacked appropriate Hong Kong introducers in the specific Hong Kong academic environments. In addition, the period of time when Hong Kong was returned to China by England might not be a perfect timing for the transfer of French feminist theories to Hong Kong because post-colonialist feminism seemed to be more attractive for Hong Kong feminists.

Almost every Western theorist must have a local translator and introducer to make way into Chinese culture. Otherwise, Western thoughts would not be able to smoothly land in China without appropriate Chinese acculturation. Take Sara Kofman in China for instance. Except for the English translation of The Enigma of Women and some Chinese professors putting it into syllabi, there was almost no way for regular Chinese folks to understand Sara Kofman at all. There were not enough kind-hearted Chinese introducers to fervently propagate Sara Kofman. Most Chinese theoretical appropriators did not choose Sara Kofman. They did not have enough motivation to whole-heartedly re-phrase/ re-paraphrase Sara Kofman. Therefore, Sara Kofman was not as popular and hot as Irigaray and Cixous in Chinese feminist theoretical discussions. Without enough enthusiastic Chinese theoretical translators, appropriators, and introducers to make the way into Chinese culture, Western feminist theorists, like Kofman, could barely land smoothly in China. If I compare American academia's appropriation of Sarah Kofman, and Catherine Clement with that of Luce Irigaray, Julia Kristeva, and Hélène Cixous, everything might be much more understandable. Sarah Kofman has almost only one book translated into English. Catherine Clément's publications were also not as popular as Kristeva's. This was why the acceptance of Clement and Kofman in the US was worse than that of Irigaray, Kristeva, and Cixous. It was not because Kofman was really weaker than Irigaray. It was not because Kofman's academic importance was less than Irigaray's. It was not because Catherine Clement was truly bad, either. 
On the contrary, Luce Irigaray, Hélène Cixous, and Julia Kristeva were ardently welcome in America not because they were better and stronger than all the other French feminists. It was because American theoretical introducers were willing to cross-culturally and cross-lingual-ly transfer these three French feminist theorists into their academic environments. Similar was the Chinese case. It was because Chinese introducers had enough motivation to transplant these three French feminists to their areas. Then, Chinese scholars indirectly applied this American/Western mainstream taste onto their reception of these three major French feminists.

When to welcome the West in order to fit in the overall Chinese foreign policy, why French feminist theories to be preferred in order to win a survival, and which French theorists to be selected in order cut down the large number of French feminists -all these were where Chinese feminist theoretical appropriators developed their cross-lingual and cross-cultural surviving-strategies within the Chinese socio-political trends of the 1990s-.

\section{APPENDIX}

1. LIN, Shuming 林樹明: “Xin shiqi nüxin zhuyi wenxue piping shuping》 (新時期女性主 義文學批評述評 «Feminist Literary Criticism on a New Age»), Wenyi lilun, 10 (1992), pp. 157-165.

2. ZHANG, Jinyuan 張京媛: “Cong xunzhao ziwuo dao dianfu zhuti: dangdai nüxing zhuyi wenxue piping de fazhan qüshi»(從尋找自我到顛覆主體: 當代女性主義文學 批評的發展趨勢 《From A Quest for Self toward A Subversion of Subjectivity: The Development of Contemporary Feminist Literary Criticism»), Wenyi lilun, 10 (1992), pp. 166-171.

3. LIN, Shuming 林樹明: «Lun liangxing gongti» (論兩性共體 “On Androgyny»), Wenyi lilun, 11 (1993), pp. 146-153.

4. LIN, Shuming 林樹明: “Nüxing zhuyi piping yu makesi zhuyi ji xianshi zhuyi shixue» (女性主義批評與馬克思主義及現實主義詩學 《Feminist Criticism, Marxism, and Poetics of Realism»), Wenyi lilun, 11 (1993), pp. 124-127.

5. ZHou, Leshi 周樂詩: «Huanzhuang: zai bianyuan he zhongxin zhijian (nüxing xiezuo chuangtong he nüxing zhuyi wenxue piping celüe»(換裝: 在邊緣和中心之間(女性 寫作傳統和女性主義文學批評策略 《The Change of Garments: Between the Margin and the Center (Women's Writing Tradition and Strategies of Feminist Literary Criticism)»), Wenyi lilun,11 (1993), pp. 128-134.

6. MA, Xinguo 馬新國: «Ping nüquan piping: xin lishi piping ji houxiandai zhuyi wenxue de fazhan tezheng qüshi»(評女權批評.新歷史批評及後現代主義文學的發展特徵 趨勢 《On The Developing Characteristics and Trends of Feminism, New Historicist, and Post Modernist Criticism»), Wenyi lilun, 8 (1994), pp. 74-82.

7. LI, Jikai 李繼凱: “Wenyi xingxue chulun» (文藝性學初論 “An Introduction to Literary and Artistic Sexology»), Wenyi lilun, 7 (1994), pp. 51-58.

8. LIN, Shuming 林樹明: «Nüxing zhuyi wenxue piping yü hou jieguo zhuyi» (女性主義 文學批評與後結構主義 《Feminist Literary Criticism and Post-Structuralism»), Wenyi lilun, 9 (1994), pp. 179-185.

9. WANG, Ning 王寧: «Nüquan zhuyi lilun yü zhongguo dangdai nüxing xianfong wenxue» (女權主義理論與中國當代女性先鋒文學 《Feminist Theory and Contemporary Chinese Women's Avant-garde Literature»), Wenyi lilun, 2 (1996), pp. 111-117. 
10. RaO, Pungzi 饒茯子 and CHEN, Lihung 陳麗虹: “Haiwai nü zuojia ji qi wenban de lilun toushi»(海外華支女作家及其文本的理論透視 《An Investigation to Overseas Chinese Woman Writers and Their Texts»), Wenyi lilun, 2 (1998), pp. 62-73.

11. Wen, Jiehua 文潔華: “Xifang nüxing zhuyi meixue: fazhan yü piping》 (西方女性主義 美學:發展與批評 《The Western Feminist Aesthetics: Development and Criticism»), Wenyi lilun, 3 (1998), pp. 45-52.

12. Liu, Siqian 劉思謙: 《Zhongguo nüxing wenxue de xiandaixing》 (中國女性文學的現代 性 «The Modernity of Chinese Women Literature»), Wenyi lilun, 4 (1998), pp. 47-58.

13. ZHANG, Yanbing 張岩冰: «Faguo nüxing zhuyi wenxue piping de yüyan lilun» (法國 女性主義文學批評的語言理論 《The Theory of Language in French Feminist Literary Criticism»), Wenyi lilun, 10 (1998), pp. 120-126.

\section{REFERENCES}

Andors, Phyllis: The Unfinished Liberation of Chinese Women, Bloomington, Indiana University Press, 1983.

Barlow, Tani E.: «Theorizing Women: Funu, Guojia, Jiating», Genders, 10 (1991), pp. 132-160.

Barmé, Geremie: "The Chinese Velvet Prison: Culture in the 'New Age,' 1976-89», Issues and Studies, 25-27 (1989-91), pp. 54-79.

—: «The Greying of Chinese Culture», China Review, 13:2 (1992), pp. 13.2-13.52.

BARTKY, Sandra Lee: "Sympathy and Solidarity: On a Tightrope with Scheler», in Diana Tietjens Meyers and Alison Jagger (eds.): Feminist Rethinking the Self, Boulder, Westview Press, 1997, pp. 177-196.

Bergner, Gwen: «Myths of Masculinity: The Oedipus Complex and Douglass's 1845 Narrative», in Christopher Lane (ed.): The Psychoanalysis of Race, New York, Columbia University Press, 1998, pp. 241-260.

Chodorow, Nancy: "The Psychodynamics of the Family», in Linda Nicholson (ed.): The Second Wave: A Reader in Feminist Theory, New York, Routledge, 1997, pp. 181-197.

Cheung, Siu-Woo: «Subject and Representation: Identity Politics in Southeast Guizhou», PhD Dissertation, University of Washington, 1996.

CHow, Rey: «Visuality, Modernity, and Primitive Passions», in Primitive Passions: Visuality, Sexuality, Ethnography, and Contemporary Chinese Cinema, New York, Columbia University Press, 1995, pp. 1-172.

Davion, Victoria: «Listening to Women's Voices: Rape, Epistemic Privilege and Objectivity", in Bat-Ami Bar On and Ann Ferguson (eds.): Daring to Be Good: Essays in Feminist Ethico-Politics, New York, Routledge, 1998, pp. 8-19.

DinG, Ling丁玲: “We de Chuangzuo Jingyan» (我的創作經驗 “My Experience in Literary Creation"), in Yuan Liangjun (袁良駿) (ed.): Ding Ling Yanjiu Ziliao (丁玲研究資 料 Research Materials on Ding Ling), Tianjin (天津), Tianjin Renmin (天津人民), 1982, pp. 105-107.

EHrLICH, Susan: "Critical Linguistics as Critical Methodology», in Sandra Burt and Lorraine Code (ed.): Changing Methods, Toronto, Broadview Press, 1995, pp. 45-73.

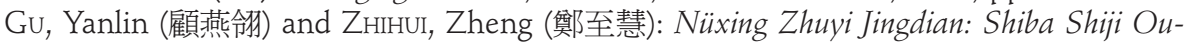
zhou Qimeng, Ershi Shiji Bentu Fansi (女性主義經典：十八世紀歐洲啓蒙，二十世紀本 土反思 Feminist Canons: European Enlightenment in the 18 $8^{\text {th }}$ Century, Local Reflections in the 20th Century), Taibei, Nüshu (女書Fem Books), 1999.

Han, Mingzhu: Cries for Democracy: Writings and Speeches from the 1989 Chinese Democracy Movement, Princeton, Princeton University Press, 1990.

Hsiung, Ping-Chun; Jaschor, Maria; Milwertz, Cecilia and Chan, Red: Chinese Women Organizing, Oxford \& New York, Berg, 2001. 
Honig, Emily: «Socialist Revolution and Women's Liberation in China -A Review Article», Journal of Asian Studie, XLIV-2 (1985), pp. 329-336.

Janknowiak, William: "Parental Affection in the Chinese Family", in Susan Brownell and Jefferey N. Wasserstrom (eds.): Chinese Femininities / Chinese Masculinities: A Reader, Berkeley, University of California Press, 2002, pp. 361-380.

JayaWardena, Kumari: Feminism and Nationalism in the Third World, London, Zed Books, 1986.

JiANG, Hong: «Feminine or (Un)feminine: Struggles over the Meanings of Femininity in Chinese Women's Literature», Women and International Development, Michigan State University, Working Paper\#272, May 2001.

Koss, Mary: «Hidden Rape: Sexual Aggression and Victimization in a National Sample in Higher Education", in Ann Wolbert Burgess (ed.): Rape and Sexual Assault, New York, Garland Press, 1988, Vol 2, pp. 3-25.

LaRson, Wendy Ann: Women and Writing in Modern China, Stanford, Stanford University Press, 1998.

LI, Xiaojiang (李小江): «With What Discourse Do We Reflect on Chinese Women? Thoughts on Transnational Feminism in China», in Yang Mei-hui (楊美惠) (ed.): Spaces of Their Own in Transnational China, Minneapolis, University of Minnesota Press, 1999, pp. 261-277.

LIANG, Jun (梁軍): “Nüxing jiaoyu shinian huigu» (女性教育十年回顧 《A Retrospect of the Ten-Year Women's Education»), in Xiaojiang Li (李小江) (ed.): Funü yanjiu yündong zhongguo ge an (婦女研究運動中國個案 Women's Education and Movement: Chinese Case Studies), Hong Kong, Oxford University Press, 1997, pp. 1-36.

Liu, Lydia H (劉禾): Translingual Practice: Literature, National Culture, and Translated modernity-China, 1900-1937, Stanford, Stanford University Press, 1995.

MacKinnon, Cathorine A: From The Sexual Harassment of Working Women: A Case of Sex Discrimination, New Haven, Yale University Press, 1979.

MENG, Yue (孟悅) and DAI, Jinhua (戴錦華): Fuchu Lishi de Dibiao: Zhongguo Xiandai Nüxing Wenxue Yanjiu (浮出歷史地表: 中國現代女性文學研究 Voices Emerging Into The Foreground of History: A Study of Contemporary Chinese Women's Literature), Taibei, Shibao (時報), 1993.

MoI, Toril: Sexual/Texual Politics: Feminist Literary Theory, New York \& London, Methuen, 1988.

Mu, Yi and Thompson, Mark V.: Crisis at Tiananmen, San Francisco, China Books \& Periodicals, 1989.

Polumbaum, Judy: "Professionalism» in China's Press Corps», in Roger V. Des Forges, Luo Ning and Wu Yen-bo (eds.): Chinese Democracy and the Crisis of 1989: Chinese and American Reflections, Albany, State University of New York Press, 1993, pp. 295-311.

Rubin, Gayle: "The Traffic in Women", in Linda Nicholson (ed.): The Second Wave: A Reader in Feminist Theory, New York, Routledge, 1997, pp. 27-62.

Rushing, Andrea Benton: "Surviving Rape», in Stanlie M. James and Abena P. A. Busia (eds.): Theorizing Black Feminisms, New York, Routledge, 1993, pp. 127-140. Reprinted in Janet Price and Margrit Shildrick (eds.): Feminist Theory and the Body, New York, Routledge, 1999, pp. 371-380.

Salisbury, Harrison Evans: Tiananmen Diary, Boston, Little, Brown, and Co., 1989.

ScheIn, Louisa: "Gender and Internal Orientalism in China", in Susan Brownell and Jefferey N. Wasserstrom (eds.): Chinese Femininities/Chinese Masculinities, Berkeley, University of California Press, 2002, pp. 385-411. 
Seldon, Mark: «Limits of the Democratic Movement», in Roger V. Des Forges, Luo Ning and Wu Yen-bo (eds.): Chinese Democracy and the Crisis of 1989: Chinese and American Reflections, Albany, State University of New York Press, 1993, pp. 107-131.

SprvaK, Gayatri C.: In Other Worlds: Essays in Cultural Politics, New York, Routledge, 1988.

STACEY, Judith: Patriarchy and Socialist Revolution in China, Berkeley, University of California Press, 1983.

TAN, Frank: «Epiphany of Press Reform», in Roger V. Des Forges, Luo Ning and Yen-bo $\mathrm{Wu}$ (eds.): Chinese Democracy and the Crisis of 1989: Chinese and American Reflections, Albany, State University of New York Press, 1993, pp. 277-294.

WANG, Zheng (王政): Women in the Chinese Enlightenment: Oral and Textual Histories, Berkeley, University of California Press, 1999.

Wolf, Margery: «The Setting of Chinese Women's Lives: Family Organization», in Revolution Postponed: Women in Contemporary China, Stanford: Stanford University Press, 1985, pp. 182-202.

YANG, Mei-hui (楊美惠): Through Chinese Women's Eyes (video), New York, Women Make Movies, 1997.

ZHANG, Jingyuan (張京媛): Dangdai nüxing zhuyi piping (當代女性主義批評 Contemporary Feminist Criticism), Beijing, Beijing University Press, 1992. 